\title{
SLOPE STABILIZATION ON CHALKOUTSI - DILESI ROAD, AT PIGADAKIA LOCATION, ATTICA PREFECTURE
}

\author{
Mourtzas N. D. ${ }^{1}$, Symeonidis K. ${ }^{2}$, Passas N. ${ }^{3}$, Alkalais E. ${ }^{4}$, Kolaiti E. ${ }^{5}$ \\ ${ }^{1}$ Geologist PhD, Gaiaergon Geotechnical Firm. , Kefallinias 16-18, 15231 Athens, Greece, \\ gaiaergon@gmail.com \\ ${ }^{2}$ Geologist MSc, Gaiaergon Geotechnical Firm. , Kefallinias 16-18, 15231 Athens, Greece, \\ gaiaergon@gmail.com \\ ${ }^{3}$ Geologist PhD, Public Works Administration of the Prefecture of Attica \\ ${ }^{4.5}$ Geotechnical Engineer, Gaiaergon Geotechnical Firm. , Kefallinias 16-18, 15231 Athens, Greece, ga- \\ iaergon@gmail.com
}

\begin{abstract}
A series of ongoing landslides occurred at the steep coastal slopes at Pigadakia location, on the road connecting Chalkoutsi and Dilesi towns, at NE Attica. These landslides caused severe disruption on local traffic.

Engineering geological study revealed the local geological conditions and the complex mechanism of the landslides. Site is located on the Neogene deposits composed mainly by layers of sandy or silty clays, marly clays with thin layers of conglomerates. Multiple landslides occurred on the steep costal slopes at a length of $280 \mathrm{~m}$ parallel to the coast line. On the upper slopes which are composed by loose clayey materials typical circular failures occurred while on the lower ones, composed by hard clays and marls, discontinuities delineate failures under the weathering influence of sea waves. Six boreholes were drilled with piezometers and inclinometers installed in order to investigate the progress of the failures. The stabilization of the upper slopes included the use of soil nails covered with geocells. The lower slopes stabilization included the protection from sea wave erosion by covering slopes with a rock fill embankment.
\end{abstract}

\section{Introduction - Project description}

This paper aims at the presentation of the consecutive slides that have been developed in the slopes of the road from Chalkoutsi to Dilesi at the location "Pigadakia", causing the reduction of the active cross-section of road and in some cases the complete interruption of the traffic. An engineering geological approach of the problem is presented along with the results of the geotechnical investigation, an analysis of the mechanism of landslides and finally the two alternative solutions for the remedial measures needed. It is noted that the final geological design, the geotechnical investigation and the preliminary and final geotechnical design of slope stabilization measures, were carried out during the period from May 2005 to October 2008 under a contract assigned by the Directorate of Public Works of Attica Perfecture. 


\section{Morphological setting}

The sheer coastal slope, along which the failures develop (Fig. 1), is the ending of the broader area's upstream hill morphology. This hill morphology has the form of an elongated ridge with gradually declining altitudes and it is directed from NE at Kamari with a peak altitude of +76.5 and terminates, at a peak of +29.9 , in the area of the study.

The drainage system, on the west side of the ridge is incomplete with lengths limited below 100m, of 2nd stream order and with limited branching but with substantial in-depth erosion, while on the east side of the ridge a stream of 3rd order is developed on a NNE direction with a high branching coefficient, a total length of some $300 \mathrm{~m}$, low dipping along the stream and with substantial in-depth erosion.

The extended, under study, failures develop into a plugging cliff, about $280 \mathrm{~m}$ length, which extend in a WNW direction, parallel to the coastline. The coastal slope, which is $38 \mathrm{~m}$ in height, to the upper part with altitude of +35 to +38 presents mild morphological slopes about $15 \%$. To the part with altitude of +29 to +35 , slopes are about $85 \%$, whereas to the rest part dip becomes extremely steep, about $100 \%$. At an average altitude of +18 to +20 the under study part of Halkoutsi - Dilesi road, about $7 \mathrm{~m}$ width, intervenes.

At the areas where the failures are occurred, steep decollement morphology appears in the upper disintegration parts. At the lower parts, where materials accumulate, exist milder and soil creep morphologies.

\section{Geological setting}

The geological substratum at the failures area is formed by the Neogene deposits of Halkoutsi-Dilesi (Mettos 1992, Koumantakis 1971) while the younger deposits include the eluvial cover, littoral deposits, landslide materials and slope erosion products.

The Neogene substratum consists of brown-red colored rotations of clay, sandy, marly and clayey clay (c-cl) beddings, with thin conglomerate and breccia (c.gr) intercalations (Fig.1, Fig.2 and Fig.3). The lower horizons at sea level seem hard and cohesive, while the upper horizons are semi-cohesive to loose with cohesive beddings insertions. The persistence of the discontinuities crossing the formation is greater than $3 \mathrm{~m}$, with planar, slightly rough surfaces, closed or with apertures up to $5 \mathrm{~mm}$, walls slightly weathered, void or with reddish clayey material and dipping at N, NW and SW directions with dips of $40^{\circ}, 85^{\circ}$ and $80^{\circ}$ respectively, forming planar and wedge failures (Fig. 1). Within the fine material appear sparse pebbles, small-sized breccias and fossil bones from mammals.

The conglomerate and breccia intercalations are continuous, planar or slightly undulating, parallel or sub-parallel, with distinct bed boundaries. They comprise of gray, brown and whitish gravels with an average size of $0.036 \times 0.022 \times 0.018 \mathrm{~m}$ and limestone pebbles, strongly cemented with light brownish to red brownish clayey-sand material. Coarse materials are poorly to very poorly sorted, with gravel shapes being spherical to tabular with subangular to subrounded roundness, while sand granules, of quartz origin, are also being spherical to tabular with angular to subrounded roundness. The conglomerate and breccia intercalations exhibit depositional structures of normal graded to composite bed sequences (Fig. 2 and Fig.3).

The, 200m total thickness, formation is the lateral and upwards transition of the Oropos fluvial-terrestrial formation and presents depositional dip, about $20^{\circ}$, towards SSW. Slopes are covered on their bases by landslide materials and slope erosion products and exhibit characteristic erosional 
structures formed by the surface water runoff. The Neogene substratum appearing along the natural and man-made slopes is presented in detail at the lithostratigraphic logs of figure 2.

The clayey nature of the Neogene deposits doesn't allow the development of aquifer zones in their masses and only at its coarse or sandy intrusions seasonal, perched, low yield aquifers can be developed, which their discharge can cause pore pressure to increase and the underlying clay layers impregnation. This impregnation, as wells as, the water infiltration can also cause the development of pore pressure and creeping at the loose landslide materials.

\section{Description of failures}

For descriptive purposes the failures that occur along the coastal forehead are divided into the upper part and the lower part in relation to the road (Fig. 1).

\subsection{Upper slope}

In this part two main and three secondary failures can be found.

The first main failure (L1) pertains to soil material fracture and sliding with head scarp altitudes from +28 to +30 and toe at the road level at +16 . The range of fracture is $18 \mathrm{~m}$ while the accumulation of sliding material, at the road level, has $21 \mathrm{~m}$ range. The second main failure (L2), which is the most important, is located about $7 \mathrm{~m}$ to the west from the previous one, with head scarp altitudes from +31 to +35 and toe at the road level at +19 , has $32 \mathrm{~m}$ range and analogical accumulation range at the toe.

However, fractures and small movements are located in the slope part upstream of the main landslides to +35.50 altitudes, thus pointing the fact that the phenomenon is developing towards upstream. The secondary failures, as well as smaller ones, are events of limited fractures and sliding-erosions of the slope and materials accumulations at the slope base. The first of those (Ls1) took place east of (L1) failure with a range of $11 \mathrm{~m}$ at an altitude of +26 while the second one (Ls2) west of (L2) failure with a range of $9 \mathrm{~m}$ at an altitude of 30.

\subsection{Lower slope}

This part exhibit the most extended failures of the area, with five main landslides and three of minor importance and numerous small sliding-erosions along the steep coastal slope.

The first main landslide (L3) presents the most significant fracture range of $75 \mathrm{~m}$, with head scarp altitude of +16 while the range of the slope base, where the sliding material accumulates, is $50 \mathrm{~m}$. The landslide materials have an estimated thickness of $3 \mathrm{~m}$, while their morphology, with repeated fractures and slides refers to an evolutionary process of the phenomenon, due to the loss of support at their base from the erosive action of sea waves. The second main landslide (L4), which is considerably smaller than the first one with a fracture range of $46 \mathrm{~m}$ and head scarp altitudes ranging from +6 to +10 , has an estimated landslide materials thickness of $1.5 \mathrm{~m}$ to $2,0 \mathrm{~m}$. The third main landslide (L5) has low fracture range about $15 \mathrm{~m}$, at an altitude of +20 , while the thick soil material of the failure presents wavy morphology -with repeated fractures and slides- which refers to an evolutionary process because of the erosive action of sea waves. The fourth main landslide (L6) has fracture range 50m and head scarp altitude of +21 and reaches the sea level with range of the accumulated soil material about $60 \mathrm{~m}$. The thickness of the landslide materials is estimated some $4 \mathrm{~m}$ and their morphology reveal the evolutionary process of the failure. The fifth main landslide (L7) at the west part of the study area concern the whole slope lower the road which is subjected to continues soil material creeping due to the 


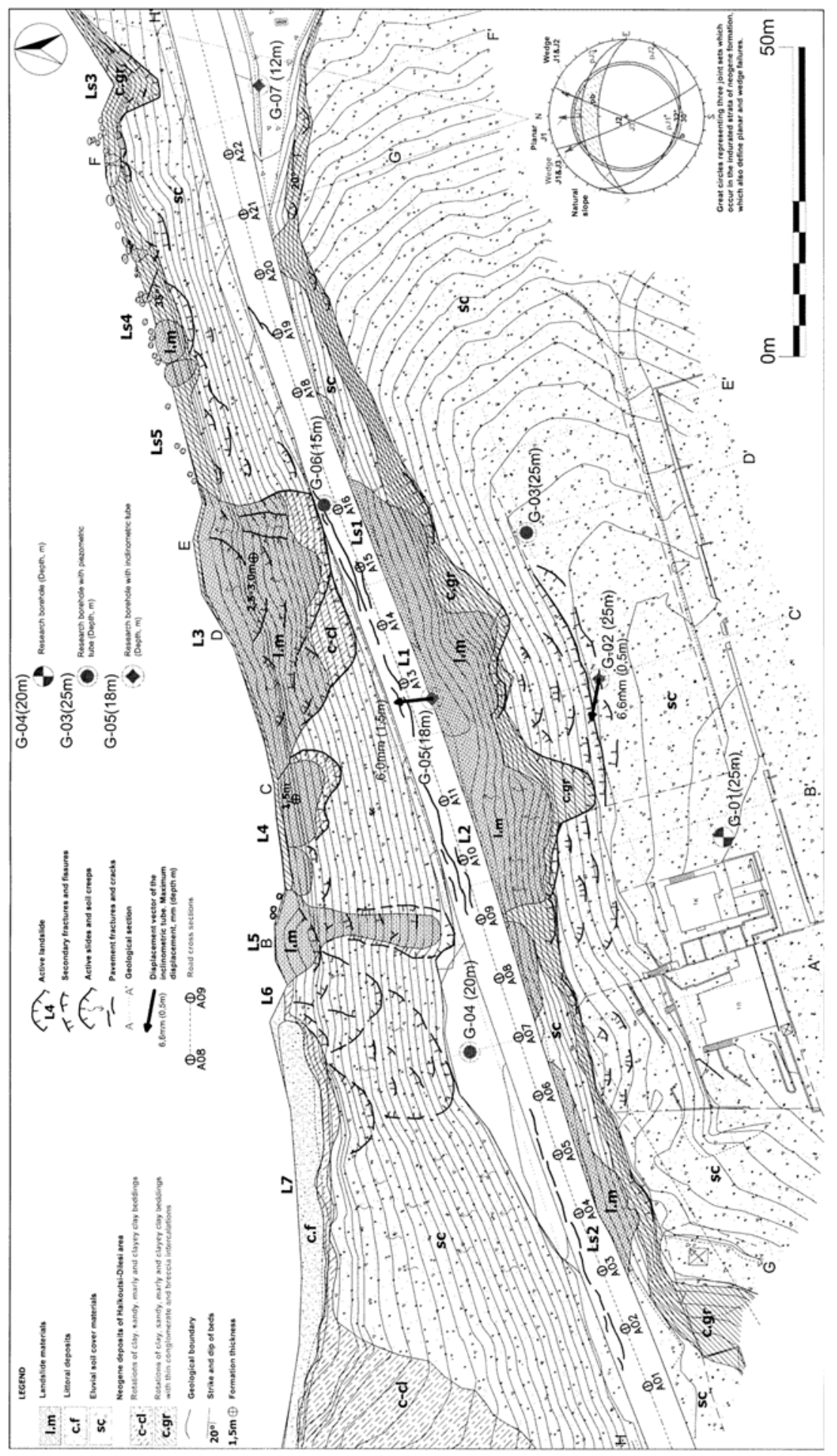

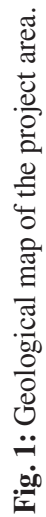




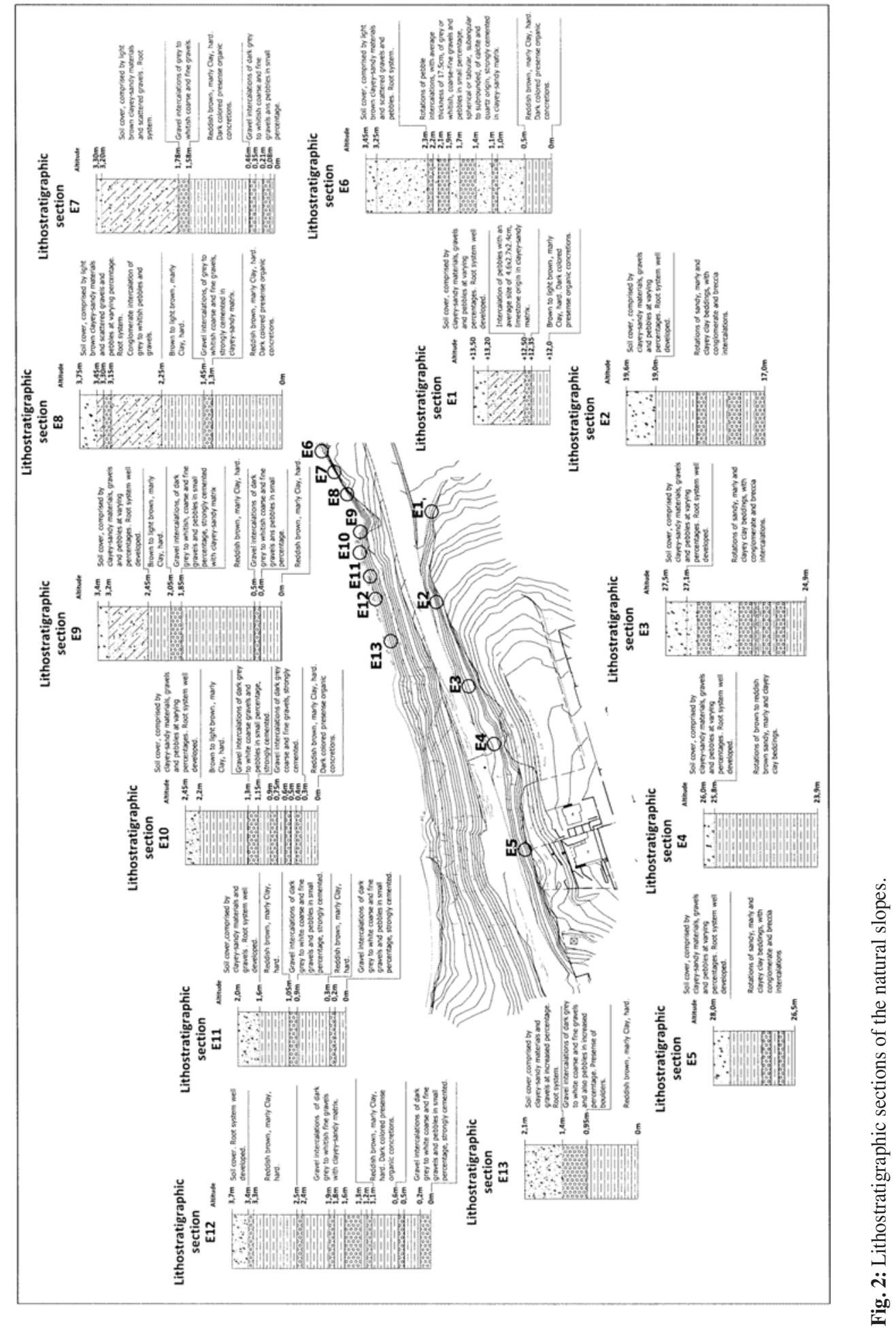




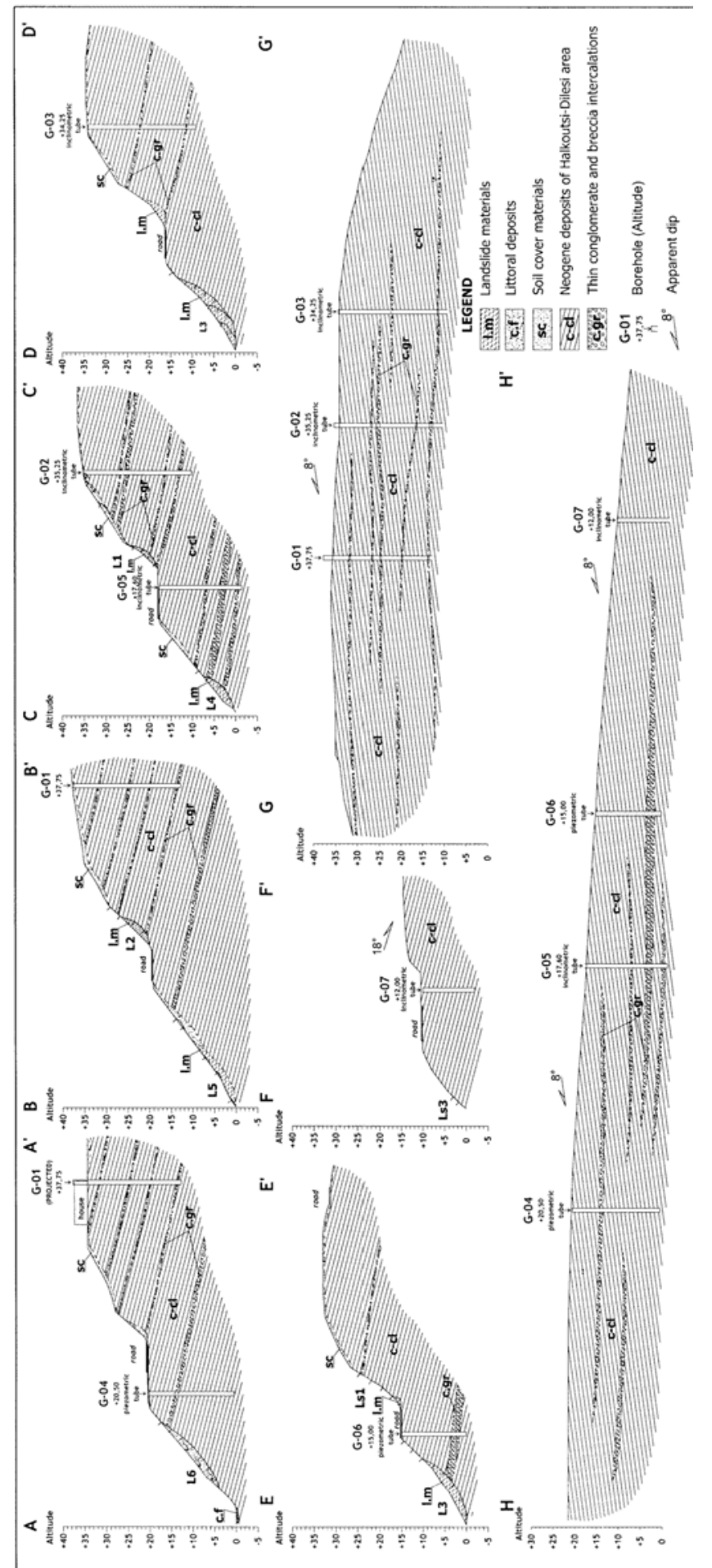

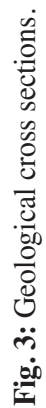


Table 1

Preparatory causal factors : 1.6, 1.9, 4.1

Triggering causal factors : 2.5, 3.1

loss of support at their base. The range of this slope part is about $70 \mathrm{~m}$ and the maximum altitude of the phenomena origination is on the road where there are continuous cracks and recessions.

The three secondary failures Ls3, Ls4 and Ls5 pertain to the east part of coastal slope which extend about $150 \mathrm{~m}$ length with a maximum altitude of +8 . These failures concern part of the slopes that are delimited by discontinuities and due to the lack of support detach and accumulate at their toe as rock blocks of a maximum diameter of $1.0 \mathrm{~m}$. The total landslides at the lower part of the road cause support deletion of the road, so the north half of the pavement present fractures, cracks and downstream movements.The main causes of the failures events according to macroscopic observation and experience from similar engineering geological behavior of other formations recapitulate as follows:

- Modification of stability conditions, provoked by the excavation for the road construction. Steep to extremely steep gradient, where the failures occur.

- High overconsolidation of the neogene deposits.

- Extensive erosion because of slope exposure to the superficial water (e.g. intense rainfalls).

- Support loss at the slope toe by the continuous erosion of the sea waves.

- Impregnation of clay layers and increase of pore pressure from water which percolates through coarse layers and relieve to the slope front.

- Presence of discontinuities in the clayey formation, which in combination with the support loss at the slope toe result in the detachment of large clayey blocks.

Based on the above, from the physical point of view, the slope can considered as "marginally stable" (Crozier, 1986 and WP/WLI (1994)). The Landslide Report after WP/WLI (1994) is presented in Table 1.

\section{Geotechnical investigation - Results}

In order to investigate the geotechnical conditions in the slides areas, seven (7) exploratory boreholes with labeling G-01 $\div$ G-07 and continuous sampling were carried out. The three boreholes (with labeling G-01 $\div \mathrm{G}-03$ ) were carried out in the upper slope of the existing road. The remaining four

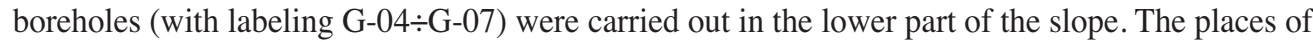
implementation of drillings are presented in Fig. 1 and the geotechnical borehole logs are presented in Fig. 4. In all the boreholes, during the drilling works Standard Penetration Tests were carried out (SPT) every 2,0-3,0m, in order to estimate the in situ consistency of clayey formations and in situ density of the granular formations. In boreholes G-03, G-04 and G-06 stand pipe piezometers were placed in order to measure the short and long term fluctuation of the water level inside the boreholes. In Table 2, measurements of the water level are presented during drilling as well as the measurements taken after the completion of the geotechnical investigation works.

In boreholes G-02, G-05 and G-07 inclinometer casings were placed, in order to monitor the size and direction of movement of the slopes. The first inclinometer measurement (reference) was taken after the completion of the investigation works (8/4/2006). Another two measurements were taken in 
Table 2

\begin{tabular}{|c|c|c|c|c|}
\hline \multirow{2}{*}{ Borehole } & \multirow{2}{*}{ Date } & \multirow{2}{*}{$\begin{array}{c}\text { Borehole casing } \\
\text { (m) }\end{array}$} & \multicolumn{2}{|c|}{ Water Level depth (m) } \\
\hline & & & Morning & Evening \\
\hline G-01 & $\begin{array}{l}17 / 3 / 2006 \\
20 / 3 / 2006 \\
21 / 3 / 2006 \\
23 / 3 / 2006 \\
24 / 3 / 2006\end{array}$ & 6,0 & $\begin{array}{c}\text { Drilling start } \\
\text { dry } \\
9,50 \\
13,00 \\
13,70\end{array}$ & $\begin{array}{l}\text { Dry } \\
3,00 \\
3,00\end{array}$ \\
\hline G-02 & $\begin{array}{l}23 / 3 / 2006 \\
24 / 3 / 2006\end{array}$ & 15,0 & $\begin{array}{c}\text { Drilling start } \\
6,30\end{array}$ & 2,30 \\
\hline G-03 & $\begin{array}{c}21 / 3 / 2006 \\
22 / 3 / 2006 \\
23 / 3 / 2006 \\
24 / 3 / 2006 \\
15 / 7 / 2006^{*}\end{array}$ & 2,40 & $\begin{array}{c}\text { Drilling start } \\
\text { dry } \\
19,0 \\
22,80 \\
\text { dry }\end{array}$ & $\begin{array}{l}\text { Dry } \\
13,50\end{array}$ \\
\hline G-04 & $\begin{array}{c}13 / 3 / 2006 \\
14 / 3 / 2006 \\
15 / 3 / 2006 \\
21 / 3 / 2006 \\
15 / 7 / 2006^{*}\end{array}$ & 7,00 & $\begin{array}{l}\text { Drilling start } \\
\text { dry } \\
\text { dry } \\
\text { dry } \\
\text { dry }\end{array}$ & $\begin{array}{l}\text { Dry } \\
\text { dry } \\
\text { dry }\end{array}$ \\
\hline G-05 & $31 / 3 / 2006$ & - & Drilling start & Dry \\
\hline G-06 & $\begin{array}{c}1 / 4 / 2006 \\
15 / 7 / 2006^{*}\end{array}$ & - & $\begin{array}{c}\text { Drilling start } \\
14,50\end{array}$ & 0,80 \\
\hline G-07 & $16 / 3 / 2006$ & - & Drilling start & dry \\
\hline
\end{tabular}

* level in piezometer

$25 / 5 / 2006$ and in 29/6/2006. The displacement vectors measured in the above time interval (approx. 3 months) along with the maximum recorded displacement (in $\mathrm{mm}$ ) and the depth, in which it was observed, are presented in Fig. 1. During that period, the recorded displacements were small ( 5$6 \mathrm{~mm})$ inside the error limits of the instrument and were presented in small depths G-02: $0,5 \mathrm{~m}, \mathrm{G}-$ 05: 1,5m, G-07: 0,5m).

After the completion of the in situ works, laboratory tests were carried out in selected borehole samples including index tests (grain size, hydrometer tests and Atterberg limits, moisture content, unit weight, degree of saturation, specific gravity and void ratio) and tests for the determination of mechanical characteristics of the samples (triaxial compression UU, CUPP, direct shear CU and unconfined compression).

According to the results of the investigation works the area is covered by formations of very hard clays of high plasticity that in their majority are unsaturated and include preexisting discontinuities, fissure planes and slickensides. In the clayey formations in various depths, dense sand-gravel layers are present, constituted mainly from clayey gravel with sand to clayey sands with gravel. 


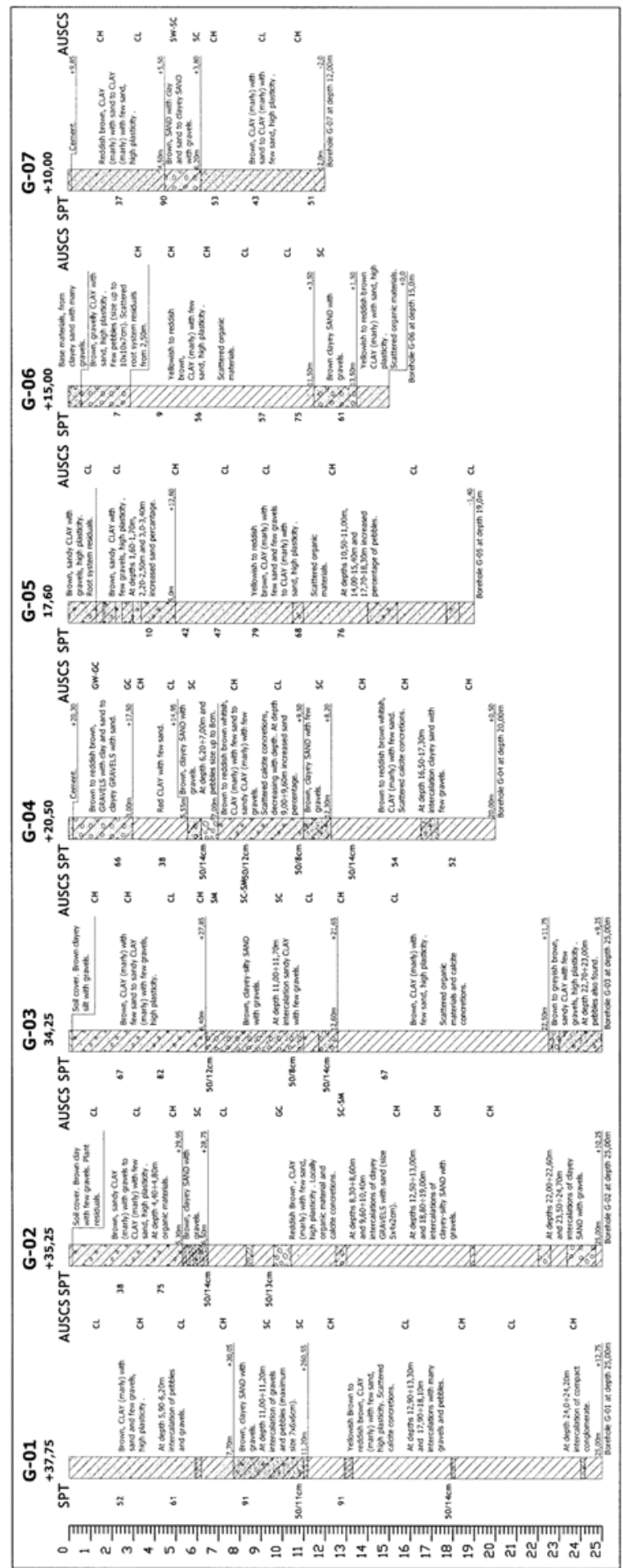

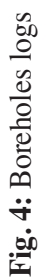


The observed slides in lower and upper slopes of the road are caused by the gradual diminishing of the shear resistance of hard clayey formations due to the progressive loss of the cohesion component of the shear strength, caused by the combined action of increased moisture content and displacements. The increase of the moisture content is caused by the infiltration of surface waters to the interior of their mass and is facilitated by the presence of the preexisting discontinuities into the body of the clay. The steep excavation slopes $\left(45^{\circ}-55^{\circ}\right)$ applied and the gradual loss of the shear strength from peak values to the fully softened values (Skempton, A.W., 1948, 1964, 1967, 1977; Terzaghi, K., Peck, R.B., Gholamreza, M., 1996) led to an increased tendency for slope displacements. In order to ensure the long term stability of the slopes an excavation with milder slopes $\left(\sim 25^{\circ}\right.$ $30^{\circ}$ ) was necessary. Regarding the lower slopes, their instability is influenced by the additional continuous erosion of the slope toe by the sea waves causing a continuous loss of their support.

\section{Soil profile - Mechanical characteristics of soil formations}

For the estimation of mechanical characteristics of soil formations presented in the upper slopes, boreholes G-01, G-02 and G-03 were carried out. According to the results of these boreholes the following soil formations were distinguished:

a. CH 1: Brown fat CLAYS, of high plasticity, with sand to sandy with a varying percentage of gravel, hard to very hard. The formation was found at depths 0.0 to 7.7 at G-01, 0.0-5.3 at G-02 and 0.0-6.4 at G-03.

b. $\mathrm{CH}$ 2: Yellowish brown to Yellowish red fat marly CLAYS, of high plasticity, with sand to sandy with a varying percentage of gravel, very hard. The formation was found at depths 11.2 to 25.0 (end) at G-01, 6.5-25.0 (end) at G-02 and 10.0-25.0 (end) at G-03.

c. SC 1: Brown clayey SANDS with gravel to clayey Gravel with sand, very dense. The formation was found at depths 7.7 to 11.2 at G-01, 5.3-6.5 at G-02 and 6.4-10.0 at G-03.

The mechanical parameters of the aforementioned formation assumed in the calculations, are presented Table 3:

Table 3

\begin{tabular}{|c|c|c|c|c|c|c|}
\hline & \multicolumn{2}{|c|}{$\mathrm{CH} 1$} & \multicolumn{2}{|c|}{$\mathrm{CH} 2$} & \multicolumn{2}{|c|}{$\mathrm{SC} 1$} \\
\hline & $\begin{array}{c}\text { Measured } \\
\text { (Peak } \\
\text { values) }\end{array}$ & $\begin{array}{l}\text { Design } \\
\text { Value }\end{array}$ & $\begin{array}{l}\text { Measured } \\
\text { (Peak } \\
\text { values) }\end{array}$ & $\begin{array}{l}\text { Design } \\
\text { Value }\end{array}$ & Measured & $\begin{array}{c}\text { Design } \\
\text { Value }\end{array}$ \\
\hline Unit weight, $\gamma \mathrm{b}(\mathrm{kN} / \mathrm{m} 3)$ & $18,5-21,2$ & 20 & $17,9-21,7$ & 20,5 & $20,5-21,0$ & 20,5 \\
\hline $\begin{array}{l}\text { Undrained shear resistance, } \\
\qquad \mathrm{Su}(\mathrm{kPa})\end{array}$ & $292,5-442$ & 250 & $229,7-697,2$ & 300 & - & - \\
\hline \multicolumn{7}{|c|}{$\begin{array}{c}\text { Effective parameters }(*: \text { Long term design values for clays - fully softened with a loss of cohesion } \\
\text { due to fissuring) }\end{array}$} \\
\hline Cohesion, $\mathrm{C}^{\prime}(\mathrm{kPa})$ & $0,0-5,0$ & $2,0^{*}$ & $0,0-97,2$ & $2,0^{*}$ & $0,0-5,0$ & 1,0 \\
\hline $\begin{array}{l}\text { Friction Angle, } \phi^{\prime} \\
\quad(\text { peak }),\left({ }^{\circ}\right)\end{array}$ & $31,5-43,5$ & $28 *$ & $14,3-41,5$ & $27 *$ & $35-37$ & 35 \\
\hline
\end{tabular}




\section{Brief description of remedial measures for upper slope}

The proposed remedial measures for stabilization concern only the slides observed in the slopes extending over the road. Remedial measures for the lower slopes were not examined, because prior to any geotechnical study for remedial actions needed, a marine design (which was not in the object of the design at hand) should identify the sea defense works to prevent the sea erosion at the slope toe (e.g. the height, thickness and blanketing material needed for the protection of slope toe due the sea waves and currents expected in the area).

For the stabilization of the upper slopes two alternative solutions of stabilization were examined. In order to choose between the two, apart from economic criteria or criteria of construction speed, legal and economic issues have also to be considered due to the need of exceeding at certain locations the limits of expropriation at the upper slope crest area.

\subsection{Solution A: Stabilization with milder excavations and soil nails}

Solution A presupposes the possibility of limited surpassing the existing limits of expropriation. Firstly a cleaning of the slope surface is carried out removing the loose failed material involved in the slides. Afterwards an excavation of the slopes with milder slopes, minimizing as much as possible the surpassing of the existing limits of expropriation of the upper slope and more specifically in the Eastern part of the slope where houses exist. For the reinforcement of the newly formed slopes and in order to achieve the required factors of safety in static and seismic loading, the placement of passive soil nails is anticipated. Finally, for the protection of clay from the surface erosion and water infiltration and for the minimization of the probability of future loss of resistance of the surficial clay layers, a cover of "soft" type (soft cover) is placed on the slope surface comprising a needle punched geotextile and a geocell cover in filled and planted with vegetation. At the crest and the slope berms a suitable collection and dewatering system (eg. ditches) of the surface water is anticipated, for the fastest possible removal of the water from the slopes (Fig. 5, left).

\subsection{Solution B: Stabilization with concrete wall founded on piles}

For the case where it is not possible to exceed the existing limits of expropriation of the upper slopes, a continuous retaining wall with a variable height is constructed at the upper slope toe. The wall will be founded on piles. The piles on one side contribute on the total stability and in the same time help in the significant reduction of required excavations in slope toe for the construction of the wall shoe, which can trigger new slides. The area between the wall and slope surface will be backfilled with granular material (eg. rock fill). The backfill slope will be 1:2 (h:b). In the crest of the backfill embankment a suitable water collection system will be constructed (eg. ditches) in order to lead all surface waters outside the wall region (Fig. 5, right).

It is pointed out that in the case of Solution A, when remedial and stabilization works will be specified for the lower slopes, due to the additional excavations needed for the removal of failed materials, in order to ensure the stability of the road and upper slopes additional temporary retaining works may have to be constructed. In such an event, a construction of a pile wall at the crest of the lower slope maybe necessary along with the placement of prestressed anchors. In the event that Solution B will be applied, due to the presence of the wall foundation piles, it is not necessary to construct a temporary retaining pile wall (Fig. 5, left). 


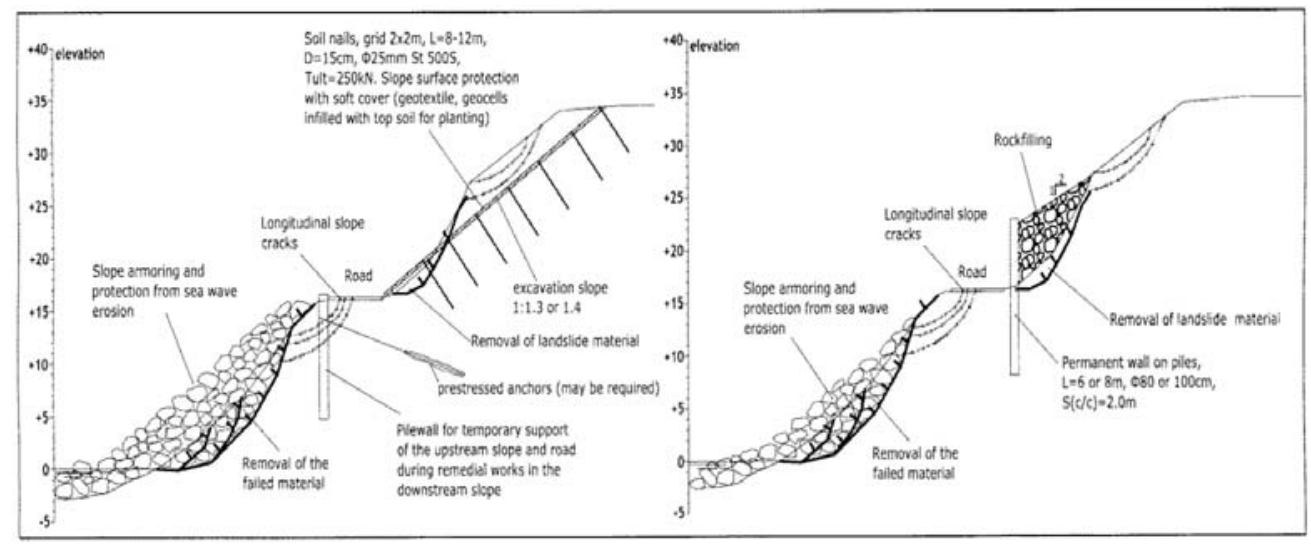

Fig. 5: Schematic reconstruction of solutions A (left) and B (right)

\section{Detailed description of Solution A - Calculations}

\subsection{Description - methodology - assumptions}

The stabilization measures of the upper slopes according to alternative solution A (Fig. 6), in more details comprises:

a) Cleaning and removal of loose failed material from the slope surface.

b) In the eastern part of the slope, between sections A03 $\div$ A09, where houses exist near the slope crest, excavation with slopes $1: 1,3\left(37,6^{\circ}\right)$ and placement permanent passive soil nails, in a grid $1,8 \times 1,8 \mathrm{~m}$ and length $\mathrm{La}=12 \mathrm{~m}$.

In the remainder part of the slope from section A $10 \div \mathrm{A} 22$, where no houses exist near the crest, excavation with slopes $1: 1,4\left(35,5^{\circ}\right)$ and placement permanent passive soil nails, in a grid $2 \times 2 \mathrm{~m}$. Due the big height of the slopes that are created in this section of the slope (up to $\mathrm{H} \sim 18 \mathrm{~m}$ ), for slopes over $9 \mathrm{~m}$ a berm is constructed having a width of $4 \mathrm{~m}$. Reinforcing soil nails at lower slope section $(\mathrm{H}<=$ $9 \mathrm{~m})$ have length $\mathrm{La}=8 \mathrm{~m}$, while in the upper section $(\mathrm{H}>9 \mathrm{~m})$ will have length $\mathrm{La}=10 \mathrm{~m}$.

c) Protection of the clayey surface with placement of a cover of "soft" type which includes a layer of a non woven needle punched geotextile and a layer of geocells in filled with soil for vegetation.

d) In the intermediary berms and the slope crest, a suitable water collection and drainage system (e.g ditches with appropriate sloping) will be constructed for the surface waters (e.g from rainfalls or other causes), in order to avoid the water concentration for large time intervals and that will probably infiltrate in the interior of the hard clay formations.

The reinforcing action of the soil nails will be required for the long term stability of the slope and for this reason should be considered as permanent. Soil nail has a diameter $\mathrm{Da}=15 \mathrm{~cm}$ and a reinforcing bar $\Phi 25 \mathrm{~mm}$ from steel S500s. Due the permanent nature of the nails, all metallic parts (reinf. bar, anchor plate, nut, protective cover e.t.c), shall be constructed from stainless steel.

For the calculations concerning the slope stability in the present study, the PC software "SLIDE" ver. the 5.27 of Rocscience was used. All calculations were carried out for the most unfavorable crosssections from the point of geometry (cross-section A09 and cross-section A14) and for the longterm stability (permanent situation) assuming the corresponding parameters for long-term conditions 

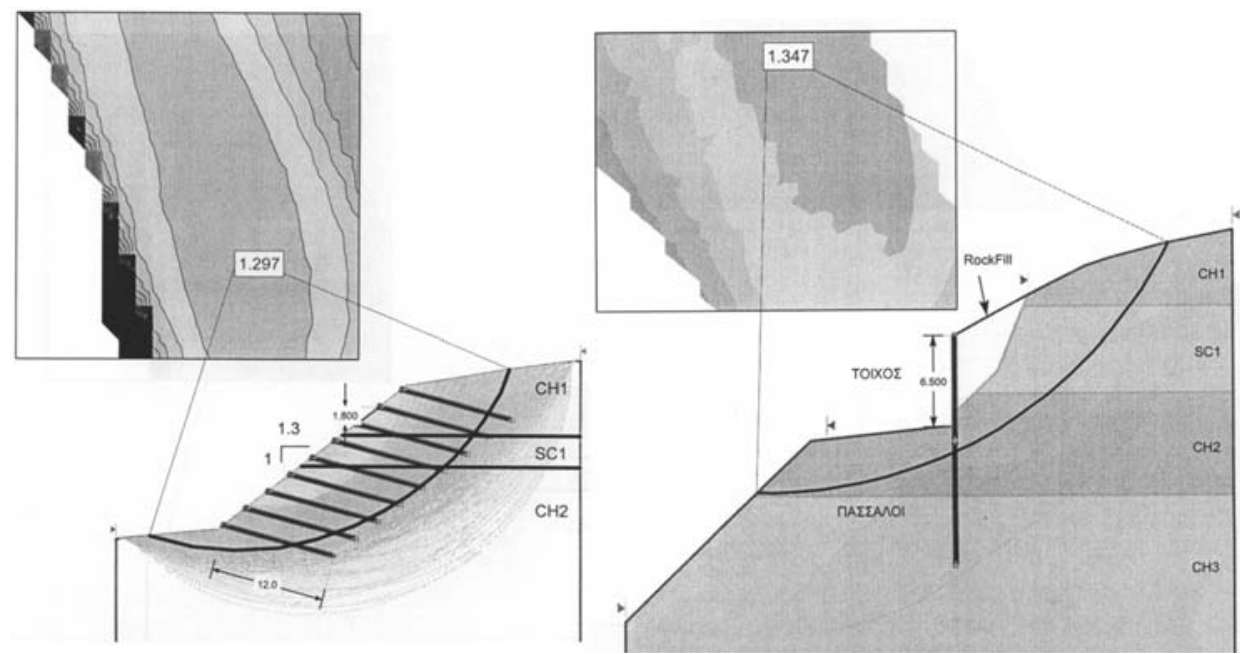

Fig. 6: Circular surfaces examined using the modified Bishop method of slices at the A09 section for remedial measures according to solution A (left) and at section A18 for remedial measures according to solution B (right).

of fully softened conditions for the clay formations and not the peak effective parameters. The calculations were carried out for static and seismic case with required factors of safety (F.S.) =1,30 and 1,00 , respectively

The ultimum side shear capacity of the nails was estimated using the expression $\tau(\mathrm{ult})=\alpha * \mathrm{Su}$, $\alpha$ : cohesion coeficient $=0,4, \mathrm{Su}$ : undrained shear resistance of clay $=250-300 \mathrm{kPa}$. And for a factor of safety $(\mathrm{FS}=2,0)$ the allowable nail shear resistance (per linear meter), is : Tal.(/l.m) $=\pi * 0,15$ x $0,4 *(250-300) / 2,0=23 \div 28 \mathrm{kN} / \mathrm{m}$

The anchor plate at the nail head has minimum dimensions of $25 \times 25 \mathrm{~cm}$ and a minimum thickness $\mathrm{t}=12 \mathrm{~mm}$.

\subsection{Calculation results}

For the determination of the slip surface with the smaller factor of safety, a large number of circular surfaces (as observed and in the actual slides) were examined covering the entire slope (the upper with the proposed measures and the lower at its present state), using the modified Bishop method of slices. The minimum factors of safety (F.S) calculated with application of the stabilizing measures of Solution A, are 1.30 and 1.02 for static and seismic loads respectively at section A09 and 1.34 and 1.04 for static and seismic loads respectively at section A14.

\section{Detailed description of Solution B - Calculations}

\subsection{Description - methodology - assumptions}

The stabilization measures of the upper slopes according to alternative solution B, in more details comprises:

a) Construction of wall foundation piles which at the same time increase the stability of the upper slope against deep sited (passing below the toe of upper slope) failure surfaces during temporary ex- 
cavations needed for the stabilization of the lower slope.

b) Construction of a reinforced concrete continuous wall and filling of the space behind the wall and the existing upper slope surface. The fill material will be granular (e.g. rockfill, ballast material) exhibiting high mechanical characteristics without requiring intensive compaction. Due to the high hydraulic conductivity of these materials, any water accumulated behind the wall can be easily removed not creating hydrostatic pressures on the wall. The slope of the granular fill behind the wall, will be 1: 2 (h:b).

c) In front of the wall and in the crest of the fill of embankment a suitable water collection and drainage system (eg. ditches with appropriate sloping) should be constructed for the surface waters as well as for the water that circulate behind the wall.

The wall height varies from $\mathrm{H}=6,5 \mathrm{~m}$ (between cross sections A16, $\mathrm{A} 17$ and $\mathrm{A} 18$ ) to $\mathrm{H}=2 \mathrm{~m}$, at the ends of the wall (cross-sections A02 and A21). Calculations concerning the general stability of the existing slopes with the proposed remedial measures (fill, wall and piles) were carried out. For the calculations of the available factor of safety, the PC software "SLIDE" ver. the 5.27 was used. All calculations were carried for the long term stability using the effective parameters for fully softened conditions for the clay formations and not the peak effective parameters. The calculations were carried out for static and seismic case with required factors of safety (F.S.) $=1,30$ and 1,00, respectively.

Calculations were performed for various wall heights $(\mathrm{H})$ and more precisely for $\mathrm{H}=4 \mathrm{~m}$ (cross-section $\mathrm{A} 7$ ), for $\mathrm{H}=5 \mathrm{~m}$ (cross-section A13) and for $\mathrm{H}=6,5 \mathrm{~m}$ (cross-section A18). Due to the fact that the clayey materials of the slopes are covered by the fill placed behind the wall, mechanisms leading to the loss of the fissured clay strength due to loss of overburden, changes of water content and temperature variations are somewhat suppressed. For this reason, for the clayey materials encountered at larger depths from the slope surface a smaller loss of cohesion is anticipated. For this reason slightly bigger values of cohesion (by $2-3 \mathrm{kPa}$ ) were used in the stability calculations in solution $\mathrm{B}$ in contrast of fully softened values used in the calculations for solution A.

For the fill material placed behind the wall (e.g rockfill, ballast) the assumed parameters for the calculations were: $\gamma=19-20 \mathrm{kN} / \mathrm{m} 3, \mathrm{c}=0 \mathrm{kPa}, \phi^{\prime}=34-35^{\circ}$.

\subsection{Calculation Results}

The minimum factors of safety calculated for solution B, by examining a large number of potential circular slip surfaces covering the entire slope (the upper with the proposed measures and the lower at its present state), using the modified Bishop method of slices, are 1.57 and 1.09 for static and seismic loads respectively at section A07,1.29 and 1.00 for static and seismic loads respectively at section A13, 1.34 and 1.04 for static and seismic loads respectively at section A14 and 1.35 and 1.00 for static and seismic loads respectively at section A18.

\subsection{Wall foundation piles}

For wall heights exceeding $\mathrm{H} \geq 5,5 \mathrm{~m}$, foundation piles having a length $\mathrm{Lp}=8 \mathrm{~m}$ and diameter $\Phi 100 \mathrm{~cm}$ are anticipated. The spacing (c/c) of piles below the wall is $\mathrm{s}=2 \mathrm{~m}$.

For wall heights smaller than $\mathrm{H}<5,5 \mathrm{~m}$, foundation piles having a length $\mathrm{Lp}=6 \mathrm{~m}$ and diameter $\Phi 80 \mathrm{~cm}$ are anticipated. The spacing (c/c) of piles below the wall is $\mathrm{s}=2 \mathrm{~m}$. 
For the dimensioning of the wall and the foundation piles, calculations were carried for static and seismic conditions. In order to estimate the bearing capacity of the piles, the methodology of DIN 4014 (03/90) was used. The response of the piles to lateral loads was calculated using equivalent elastoplastic soil springs for short term and long term conditions.

\section{Conclusions}

The observed slope failures in the upper slopes were triggered by the heavy rainfall in combination with the steep excavation slopes applied for the road construction. The observed failures in the lower slopes are mainly triggered by the continuous wave erosion at the slope toe.

Two alternative solutions of stabilization were examined for the upper slopes which offer the required safety for the whole slope (upper and lower) assuming the conditions of the lower slope remain at the present state. Since changes at the lower slope toe due to sea wave erosion cannot be excluded sometime in the future, a marine design should be carried out to determine the appropriate armoring works.

The stabilization solution which will be adopted, apart to cost effectiveness and construction speed has to take into account legal and economic issues due to liabilities to property owners at the upper slope crest area.

\section{References}

Crozier, M.J., 1986. Landslides - Causes, consequences and environment, Croom Helm, London, 252 p.

Mettos, A., 1992. Geological and Palaeogeographic study of the neogene and quaternary continental formation of NE Attiki and SE Boeotia. PhD Thesis Dept. of Geology Unv. of Athens.

Koumantakis,I., 1971. Chalkoutsi Pontian formations, S. Attica. Ann. Geol. Pays Hellen., 27, 274-284.

Popescu, M.E., 1994. A suggested method for reporting landslide causes, Bulletin of the International Association of Engineering Geology, Paris, 50, 71-74.

The rate of softening in stiff fissured clays, with special reference to London Clay. Proc. 2nd Int. Conf. Soil Mech. Rotterdam, 2, pp. 50-53.

Skempton, A.W., 1948. The rate of softening in stiff fissured clays, with special reference to London Clay. Proc. 2nd Int. Conf. Soil Mech. Rotterdam, 2, pp. 50-53.

Skempton, A.W., 1964. Long term stability of clay slopes. Geotechnique 14, No. 2, pp. 77-101.

Skempton, A.W., \& Petley, D.J., 1967. The strength along structural discontinuities in stiff clays. Proc. Geotech. Conf. Oslo 2, pp. 29-46.

Skempton, A.W., 1977. Slope stability of cuttings in Brown London Clay. Special Lectures Section, Proc. of the 9th Int. Conf. on Soil Mech. and Found. Eng., Tokyo, Vol. 3, pp. 261-270.

Terzaghi, K., Peck, R.B., Gholamreza, M., 1996, Soil mechanics in engineering practice, John Wiley \& Sons Inc. 